\title{
Et par pointer om skæve læsninger i historien og i Norden
}

er et af de centrale betegnelser for 1990ernes konstruktivistiske forskning i køn og seksualitet. Queer teorier - eller skæv-teorier - har rødder tilbage i 1970ernes amerikanske seksualitetsforskning og til poststrukturalistiske teoridannelser, som bl.a. er udviklet af den franske idehistoriker Michel Foucault og amerikanske forskere som Eve Kosofsky Sedgwick og filosoffen Judith Butler. Hvor de empiriske seksualitetsstudier i 1970erne og 1980erne havde homoseksuelle som genstandsfelt, opererer queerparadigmet i dag med bredere kønsog seksualitetsforståelser. Queerperspektiverne inspirerer i dag forskning indenfor en bred vifte af emner på tværs af humanistiske, samfundsvidenskabelige og transfaglige techno-science studier. Nøglebegreber er heteronormativitet, homosocialt begær, grænsefigurering, cross-dressing og forestillinger om køn som maskerade,

Queer i denne brede forstand som de/t skæve, trænger sig på i kulturen og i sam- 
fundet i disse år. Og noget tyder på, at det skæve eller queer bliver et af de træk, der kommer til at dominere det første tiår af det nye årtusinde. Det skæve dukker med andre ord op alle steder, i adfærd, i kulturen og $\mathrm{i}$ forskning og som et perspektiv $\mathrm{i}$ forskning og vidensproduktion.

Selv den historieforskning, der gerne vil identificere sig med den historiske kanon, hvor en central markør stadig er objektivitet og begxrløshed, kommer mod sin hensigt til at tematisere det skæve, netop fordi tiden er så proppet og parat til at opfange det skæve signal. Et nyligt eksempel på det er Hans Bondes mislykkede forsøg på at skrive den kendte danske gymnastikfører Niels Bukh, en homofil, karismatisk og højreradikal gymnastikleder ind $\mathrm{i}$ den historiske kanon. Nrrmere betegnet ind i den danske højreradikalismes kringlede udvikling i mellemkrigstiden. Når jeg siger mislykket, er det ikke, fordi afhandlingen i og for sig er dårligere end så mange andre afhandlinger. Faktisk er den ret læseværdig. Men mislykket i den forstand, at forfatteren ikke benytter sig af denne historisk enestående situation til at sige noget nyt og til at rykke rammerne for, hvad der kan siges og gøres i historisk forskning. Hans Bonde forsøger med stor iver at skubbe hovedpersonens homoseksualitet ind under privatlivets fred, men det ligger alligevel som en ubearbejdet strøm under hele fortællingen, at denne store gymnastikleder i den grundtvigianske ungdomsbevægelse var homoseksuel eller bøsse. Det antydes, at hans avancerede og enestående udvikling af mandsgymnastikken havde noget at gøre med denne subjektive sprække. Afhandlingen kunne med udgangspunkt heri have fortalt en langt mere tidssvarende og avanceret historie, såfremt Hans Bonde havde gjort det, der ikke engang længere er særlig forbudt, til det centrale. ${ }^{1}$

Det er interessant, at også parallelbevægelsen Indre Mission og den kristelige ungdomsbevægelse KFUM i den her optik kan ses som en af de helt store producenter af skæve og anderledes mandligheder. Lige fra den kendte ungdomsfører og præst Olfert Richard til Jan Sjursen som inkarnationen af dagens bløde mand. Olfert Ricard var aktiv i KFUMs storhedstid i begyndelsen af det 20. århundrede og hans karisma, bøssede konnotationer og xstetiserede religiøse budskab kan indenfor sin egen horisont måle sig med gymnastikkens og grundtvigianernes Niels Bukh.

Når det gælder den kanoniserede kirkehistorieskrivning, er dette for så vidt ikke noget nyt. Den grundtvigiansk orienterede kirkehistoriker P.G Lindhardt, hvis værker i mange årtier har domineret dansk kirkehistorisk forskning og forestillingsverden, udpegede allerede i 1950erne Olfert Ricard og den homofile lummerhed i den kristelige ungdomsbevægelse som endnu et eksempel på afsporethed og dekadence i den kristelige ungdomsbevægelse og en naiv og forenklet religiøs horisont. ${ }^{2}$ Dette er bare et af mange eksempler på, hvordan spørgsmål om køn, især hvad angår maskulinitet og mandlighed, allerede i mange år har været et element i konstruktionen af magt og hierarkier i den danske kultur.

Med andre ord mener jeg, at der kunne kommet meget sprendende og nyt ud af at queere de søjler, som ses som bxrende for den historiske kanon og den store fortælling om Danmark: søjler som grundtvigianisme, Indre Mission, socialisme og arbejderbevægelse, kulturradikalisme og feminisme. Her byder queer - eller de skæve læsninger sig til som et perspektiv, der kan se disse overskridelser, som jeg har nævnt et par eksempler på, og som der sagtens kunne findes endnu flere af (Harald Bergstedt i Socialdemokratiet, Anna Westergaard i kvindebevægelsen etc.). Ikke som tilfældige afvigelser, men som kulturelt produktive og af betydning for erkendelse af menneskelig mangfoldighed og kreativitet. $\mathrm{Og}$ i videre forstand som konstituerende for de bevægelser og strømninger, der har gjort Danmark til det, som det er i dag. Alt $\mathrm{i}$ alt kan inddragelse af sådanne per- 
spektiver tilføre det historiske felt dynamik og xndre og udfordre den historiske kanon.

\section{QUEER I NORDISK PERSPEKTIV.}

Som mange vil vide, fungerer queer-perspektiver i den aktuelle kønsforskning som et slags klondyke, der graves mange steder og fra mange vinkler og resultaterne er tilsvarende mangfoldige og forskellige. Som det f.eks. blev tydeligt ved konferencen om skæve køn, som blev afholdt af Koordinationen for Kønsforskning for et år siden. Her blev der præsenteret queerlæsninger af forskellige politiske hotte emner som etnicitet, tv-serier og populærkultur og af den litterære kanon. Navnlig det sidste kunne og burde inspirere andre faglige discipliner til nye læsninger og analyser af traditionelle emner.

Når det gælder dansk kønsforskning, har feltet været ganske meget præget af queerinspirerede tilgangsvinkler i 1990erne, selvom overskriften ofte har været nogle andre. Som f.eks. poststrukturalisme, konstruktivisme eller postfeminisme lidt afhængig af faglig disciplin og ståsted. Jeg behøver blot at nævne Dorte Marie Søndergaard: Tegnet på kroppen og historiske og sociologiske analyser som Karin Lützen: Byen temmes og Henning Bech: Når mand mødes. Også Kvinder, Køn \& Forskning har løbende bragt artikler med og om queer-perspektiver af bl.a. Tiina Rosenberg og Mette Liv Mertz.

I et nordisk komparativt perspektiv er det interessant at iagttage den ujæevne reception af det queer-orienterede og poststrukturalistiske paradigme i denne bredere forstand. I Danmark ser det således ud som om, at 70ernes og 80ernes empirisk/marxistisk inspireret feministisk kvindeforskning imploderede eller måske rettere undergik en metamorfose, da den poststrukturalistiske eller postfeministiske forskning kom på banen i slutningen af 1980erne. Det, som vi oplever i dansk kønsforskning i dag, er således ikke først og fremmest polarisering, men forskning der er mere eller mindre inspireret af poststrukturalistiske, konstruktivistiske og queerede tilgange i et bredt spektrum fra blød til hård eller radikal konstruktion. Den tilsyneladende fredelige sameksistens mellem forskellige retninger og tendenser kan også bunde i det pragmatiske faktum, at der i Danmark kun har været afsat fă ressourcer til kønsforskning i netop denne periode. Og man kan godt forestille sig, at konflikter kan blusse op netop i forbindelse med ressourcetildelinger.

Både i Norge og i Sverige ser det ud som om, at den poststrukturalistiske forskning og queer-perspektiverne har haft vanskeligere ved at trænge igennem, og at der $\mathrm{i}$ 1990erne har været tale om et konfliktforhold til den etablerede kvindeforskning. F.eks. har der i det norske tidsskrift Kvinneforskning over en årrække været tale om ret skarpe positioneringer i den forskningsstrategiske debat, ligesom forskere har gjort krav på, at queer og poststrukturalistisk forskning skal fremmes og have del i penge og prestige. Også i Sverige har queerforskning været positioneret som et selvstændigt felt $\mathrm{i}$ front mod feministisk forskning. ${ }^{3}$

Når det gælder den positionerede debat i Norge og Sverige må det bl.a. ses i lyset af den stærke statsfeministiske tradition i disse lande, som har været knyttet til en mere empirisk og mere institutionaliseret kvindeforskning. Alt i alt har det betydet skepsis overfor forskning, der ikke har kunnet godtgøre sin umiddelbare politiske nytteværdi. Situationen i Danmark har været anderledes med en svagere institutionalisering og muligvis af samme grund en mere teoretisk orienteret kønsforskning.

Det vil være oplagt og spændende at gøre hele denne kvinde- og kønsforskningens genealogi til genstand for et nordisk komparativt projekt. 


\section{NOTER}

1. Hans Bonde: Niels Bukh-En politisk-ideologisk biografi. Om grundlæggeren af Ollerup Gymnastikhøjskole. Et personligt og politisk drama om en verdensberømt danskers storhed og fald. Museum Tusculanums Forlag 2001.

2. Hilda Rømer Christensen: Mellem back-fishe og pane piger. Kon og kultur i KFUK 1880-1940.

Museum Tusculanums forlag 1995.

3. Se f.eks.Annick Prieur og Bera Ulstein Moseng:
«Sorry, we don't speak Queer». En kritisk kommentar til queer teori in Kvinneforskning 3-4.2000: Skeive perspektiver på kjønn og Harriet Bjerrum Nielsen: Rommet mellom sitering og dekonstruksjon in Kvinneforskning 1.2000: Empirisk forskning etter poststrukturalismen. For Sverige se Lambda Nordic, Tidskrift for Homosexualitet $1989 \mathrm{ff}$.

Hilda Rømer Christensen, ph.d. Koordinator for Kønsforskning 